\title{
The Design Of The Spk In Fulfilling The Production Target Of Vegetable Availability In Lut Tawar Sub-District Uses The SAW Method
}

\author{
Rayuwati $^{1}$ Yelli Novelia Putri ${ }^{2}$ \\ ${ }^{1,2}$ Universitas Gajah Putih, Prodi Teknik Informatika \\ 1rayuwati68@gmail.com, ${ }^{2}$ yellinoveria@gmail.com
}

\begin{tabular}{|c|c|}
\hline Article Info & ABSTRACT \\
\hline & \multirow{5}{*}{$\begin{array}{l}\text { Efforts to meet the availability of vegetables in fulfilling vegetable intake, } \\
\text { especially for people in Lutawar sub-district, Central Aceh district, } \\
\text { community agriculture requires a technology development that supports the } \\
\text { calculation of production at each harvest and can also determine the } \\
\text { fulfillment of community food availability. In this case, the fulfillment of } \\
\text { production targets for the availability of vegetables will be very effective if it } \\
\text { is calculated using a decision support system application, using the Simple } \\
\text { Additive weighting (SAW) method. }\end{array}$} \\
\hline Received September 22020 & \\
\hline Revised December 282020 & \\
\hline Accepted January 22021 & \\
\hline Keywords: & \\
\hline $\begin{array}{l}\text { Decision support system, } \\
\text { Production target, Vegetables, } \\
\text { Simple Additive Weighting }\end{array}$ & $\begin{array}{l}\text { The process of collecting and analyzing data is carried out systematically and } \\
\text { logically using a survey, which is to collect as much data as possible about } \\
\text { the vegetables found in Lut Tawar Subdistrict, which is a decision support } \\
\text { for the quality of the research. Then analyze vegetables in meeting } \\
\text { production targets and food availability. Application of the Simple Additive } \\
\text { Weighting (SAW) method into a decision support system to create a decision } \\
\text { support system for food availability that is assessed from its production, } \\
\text { including } 4 \text { criteria used to make an assessment, C1: Productivity, C2: } \\
\text { Harvest Area, C3: Area Planting, C4: Population, then decision making } \\
\text { assigns weight to each criterion. The types of vegetables as an alternative in } \\
\text { this study are as follows. }\end{array}$ \\
\hline
\end{tabular}

\section{Corresponding Author:}

Rayuwati,

Fak Teknik, Prodi Teknik Informatika

Universitas Gajah Putih,

Jalan Sp. Kelaping Lukub Badak. Kec Pegasing kab. Aceh Tengah, Indonesia.

Email: rayuwati68@gmail.com

\section{INTRODUCTION}

Efforts to meet the availability of vegetables in meeting vegetable intake, community agriculture requires the development of technology that supports the calculation of production at each harvest and can also determine the fulfillment of community food availability. In this case, the fulfillment of production targets for the availability of vegetables will be very effective if calculated using a decision support system application.

There are still many people whose vegetable intake is below the recommended amount of 25-30 grams/day. The recommended intake of vegetables is 3-5 servings per day.[1] Indonesians only eat vegetables as much as $40.35 \mathrm{~kg} /$ capita / year, compared to the recommendation of the United Nations Agency which deals with food and agricultural matters (FAO), namely the ideal vegetable consumption is $91.25 \mathrm{~kg} / \mathrm{capita} /$ year. The United Nations Health Organization (WHO) recommends 400 grams of fruit and vegetables per day. The American Heart Association recommends 8 servings / 4.5 bowls of a variety of fruits 
and vegetables per day. While Health Law no. 36 of 2009 recommends that people consume 3-5 servings of vegetables and 2-3 servings of fruit per day. [2]

In this case a decision support system will be very helpful in determining the fulfillment of vegetable production targets, to meet the food availability that must be met by every community., with the Simple Additive Weighting (SAW) method, and this method has often been used in terms of decision makers such as: Designing and Making a Decision Support System for Determining the Best Employees Using the Saw Method at Pt Iss Indonesia Medan Branch (Olven Manahan 2016) [3], System Decision Support for Hotel Selection in Palembang City Using the Simple Additive Weighting (SAW) Method (Dwi Citra Hartini, et al., 2013) [4], Decision Support System for Assessment of Orchid Plants in Ud. Sanjiwani Orchid Using the Simple Additive Weighting Method (Erni Dianasari, Taufik Baidawin2015) [5], Determining Superior Craft Products Using Madm-Saw, (Fera Tri Wulandari, Setiya Nugroho, 2015) [6].

\subsection{Food Security}

The occurrence of food insecurity, caused by not achieving the target of food availability and access to food for the community, [7] The World Health Organization defines three main components of food security, namely food availability, food access and food utilization. Food availability is the ability to have a sufficient amount of food for basic needs. Access to food is the ability to have the resources, both economically and physically, to obtain nutritious food. Utilization of food is the ability to use food ingredients correctly and appropriately proportionally. FAO added a fourth component, namely the stability of the three components over a long period of time.

The Food Law No.7 of 1996 states that the conditions for the fulfillment of food needs for households are reflected in the availability of sufficient food, both in quantity and quality, safe, equitable and affordable. [8] Meanwhile, USAID (1992) states the condition when everyone has physical and economic access at any time to get their consumption needs to live a healthy and productive life. FIVIMS (2005) states the condition when all people at all times physically, socially and economically have access to adequate, safe and adequate food.nutritious to meet consumption needs and according to his taste (food preferences) for an active and healthy life [8]

Vegetables are one of the main sources of micronutrients, a source of vitamins and minerals as regulating substances. Kinds of Super Healthy Vegetables and Their Benefits and Nutritional Content [9]

\subsubsection{Chayote}

Chayote's nutritional content Pumpkin siem contains several vitamins and other important nutrients. One and a half cup serving provides about $17 \%$ of your daily vitamin $\mathrm{C}$ needs. In addition, these vegetables also contain vitamin B complex, such as folate at $61 \mathrm{mcg}$ and small amounts of niacin, thiamin, riboflavin, pantothenic acid and vitamin B6. Vitamin B plays an important role in the body's metabolic processes. In addition, this pumpkin fruit also contains minerals such as iron, manganese, phosphorus, zinc and copper.

\subsubsection{Bean}

Beans are a type of legume that can be eaten either directly or by cooking them first. Both the fruit, seeds, or leaves have been widely used as delicious vegetables. Green beans are very rich in nutrients and nutrients and this type of vegetable is believed to come from the South American region. Beans contain several nutrients that are needed by the human body. Some of the nutritional content in these beans include Vitamin A, Vitamins B1, B2, B3, B6, B11, Vitamin C, Fat, Protein, Ash content, Manganese, Molybdenum, Magnesium, Potassium, Iron, Phosphorus, Calcium, Copper, Carbohydrates, Crude fiber, etc.

\subsubsection{Tomato}

Tomatoes are known to contain a type of powerful antioxidant called Lycopene in large quantities, Lycopene is a substance that makes this fruit red. Not only that, tomatoes have also been shown to contain a compound called alpha lipoic acid, which helps control blood glucose, increases vasodilation and protects against retinopathy in diabetic patients, and can even help preserve the brain and nervous tissue.

\subsubsection{Long beans}


Consumption of vegetables is very good for health. There are many vegetables that are very beneficial. One of which islong beans, Long beans are one of the vegetables that are easy to find, besides the relatively cheap price makes this vegetable popular with many people. Usually long beans are used to make various vegetables such as lodeh, pecel, stir-fry long beans and are also used for fresh vegetables. Long beans have many nutrients that are good for the body, such as vitamins B1 and B2. Both vitamins are very good for body health. Especially for those of you who have a body that gets tired easily.

\subsubsection{Sawi / Petsai}

Sawi is a vegetable that is rich in vitamins, so it is known to be very beneficial for health as well as being able to prevent various diseases. The nutritional content in mustard greens include vitamin $\mathrm{A}$, vitamin $\mathrm{K}$, vitamin $\mathrm{C}$, flavonoids, carotenoids, folate, thiamin, pantothenic acid, phosphorus, potassium to phytonutrients which make the benefits of mustard greens very diverse and varied.

\subsubsection{Cauliflower}

Nutritional content in Cauliflower Cauliflower is a source of vitamin C (ascorbic acid), folate, vitamin K (phylloquinone) and vitamin B-6. Vitamins B1 (thiamine), B2 (riboflavin), B3 (niacin), and small amounts of vitamin E (alpha-tocopherol). Cauliflower also provides essential minerals like calcium, magnesium, phosphorus, potassium and manganese without the harmful cholesterol. It is a great source of protein, and a very low amount of saturated fat, rather than the beneficial unsaturated fats and omega- 3 fatty acids. Cabbage also contains fiber and contains lower natural sugars, when compared to other family members such as broccoli. The cauliflower we are most familiar with is white, but there are actually varieties of cauliflower that are other than white in color: Green: Green cauliflower is also referred to as broccoflower. There are also two known forms here, that is, the normal form and the pointed variant called Romanesco broccoli. Purple: Cauliflower is purple due to its anthocyanins, which are substances known as antioxidants that affect the color of the vegetables. Orange: Orange cauliflower is very nutritious because it contains more vitamin A than the white variety.

\section{RESEARCH METHOD}

The problem discussed in this study is to create a system for calculating vegetable production in meeting production targets using the SAW method. The research methodology in this study is described as in Figure 1.

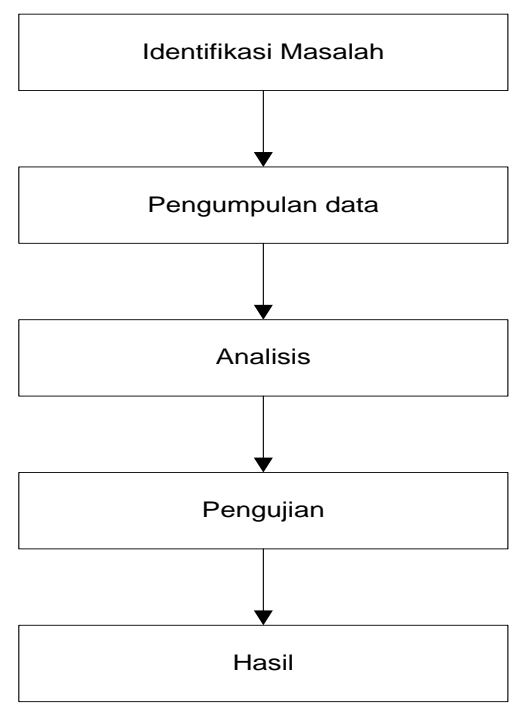

Figure 1. Research methodology 


\subsection{Data Collection}

The data collected in the form of harvest productivity data, harvested area, plant area and population conducted in Lut Tawar District, Central Aceh Regency

\subsection{Vegetable Data and Population [10]}

Table 1. Planted Area, Harvest Area \& Production of Chayote

\begin{tabular}{clccc}
\hline No. districts & & $\begin{array}{c}\text { Large } \\
\text { Plant (Ha) }\end{array}$ & $\begin{array}{c}\text { Large } \\
\text { Harvest (Ha) }\end{array}$ & $\begin{array}{c}\text { Productivity } \\
\text { (kw / ha) }\end{array}$ \\
\hline 1. & Linge & - & - & - \\
2. & Atu Lintang & 12 & 3 & 1,860 \\
3. & Jagong Jeget & 6 & 2 & 2,880 \\
4. & Star & - & 2 & \\
5. & Bargaining Lut & 5 & 2 & 120 \\
6. & Plumpness & 6 & 6 & 1,200 \\
7. & Pegasing & - & - & 248 \\
8. & Bies & 6 & 3 & 2,950 \\
9. & Bebesen & 10 & 20 & 14,878 \\
10. & Kute Panang & 4 & 34 & 3,090 \\
11. & Choose Nara & 6 & 10 & 939 \\
12. & Ketol & 3 & 24 & 283 \\
13. & Celala & 1 & 1 & 9,050 \\
14 & Rusip Between & 5 & 12 & \\
& total & $\mathbf{6 4}$ & $\mathbf{1 1 9}$ & 2014 \\
\hline
\end{tabular}

Planted Area, Harvest Area \& Chayote Production in Central Aceh Regency, 2014

Table 2. Planted Area, Harvested Area \& Bean Production

\begin{tabular}{clccc}
\hline No. districts & & $\begin{array}{c}\text { Large } \\
\text { Plant (Ha) }\end{array}$ & $\begin{array}{c}\text { Large } \\
\text { Harvest (Ha) }\end{array}$ & $\begin{array}{c}\text { Productivity } \\
\text { (kw / ha) }\end{array}$ \\
\hline 1. & Linge & 2 & 1 & 13 \\
2. & Atu Lintang & 30 & 15 & 2,490 \\
3. & Jagong Jeget & 4 & 1 & 240 \\
4. & Star & - & 2 & \\
5. & Bargaining Lut & 8 & 3 & 105 \\
6. & Plumpness & - & - & - \\
7. & Pegasing & 6 & - & 202 \\
8. & Bies & 4 & 1 & 360 \\
9. & Bebesen & 20 & 12 & 440 \\
10. & Kute Panang & 15 & 16 & - \\
11. & Choose Nara & - & - & - \\
12. & Ketol & - & - & 126 \\
13. & Celala & 1 & 3 & 3,900 \\
14 & Rusip Between & 25 & 14 & \\
& total & $\mathbf{1 1 5}$ & $\mathbf{6 6}$ & 2014 \\
\hline
\end{tabular}

Planted Area, Harvested Area \& Bean Production in Central Aceh District, 2014

Table 3. Planted Area, Harvest Area \& Tomato Production

\begin{tabular}{clccc}
\hline No. & districts & $\begin{array}{c}\text { Large } \\
\text { Plant (Ha) }\end{array}$ & $\begin{array}{c}\text { Large } \\
\text { Harvest (Ha) }\end{array}$ & $\begin{array}{c}\text { Productivity } \\
\text { (kw / ha) }\end{array}$ \\
\hline 1. & Linge & 3 & 2 & 678 \\
2. & Atu Lintang & 57 & 23 & 9,430 \\
3. & Jagong Jeget & 10 & 5 & 3,150 \\
4. & Star & 52 & 18 & 3,614 \\
5. & Bargaining Lut & 60 & 28 & 9,070 \\
6. & Plumpness & 8 & 3 & 1,110 \\
7. & Pegasing & 45 & 29 & 9,405 \\
8. & Bies & 5 & 8 & 1,641 \\
\hline
\end{tabular}




\begin{tabular}{clccc}
\hline 9. & Bebesen & 41 & 19 & 975 \\
10. & Kute Panang & 15 & 18 & 3,200 \\
11. & Choose Nara & 30 & 14 & 8,972 \\
12. & Ketol & 15 & 39 & 3,606 \\
13. & Celala & 4 & 10 & 4,260 \\
14 & Rusip Between & 15 & 13 & 3,300 \\
& total & $\mathbf{3 6 0}$ & $\mathbf{2 1 9}$ & \\
\hline
\end{tabular}

Planted Area, Harvested Area \& Tomato Production in Central Aceh District, 2014

Table 4. Planted Area, Harvested Area \& Long Bean Production

\begin{tabular}{|c|c|c|c|c|}
\hline No. & districts & $\begin{array}{c}\text { Large } \\
\text { Plant (Ha) }\end{array}$ & $\begin{array}{c}\text { Large } \\
\text { Harvest (Ha) }\end{array}$ & $\begin{array}{c}\text { Productivity } \\
\text { (kw / ha) }\end{array}$ \\
\hline 1. & Linge & 1 & 2 & 222 \\
\hline 2. & Atu Lintang & 6 & 10 & 2,590 \\
\hline 3. & Jagong Jeget & - & - & - \\
\hline 4. & Star & - & - & - \\
\hline 5. & Bargaining Lut & 8 & 6 & 390 \\
\hline 6. & Plumpness & - & - & - \\
\hline 7. & Pegasing & - & - & - \\
\hline 8. & Bies & 2 & 1 & 260 \\
\hline 9. & Bebesen & 10 & 20 & 370 \\
\hline 10. & Kute Panang & 11 & 10 & 1,260 \\
\hline 11. & Choose Nara & 3 & 3 & 485 \\
\hline 12. & Ketol & - & - & - \\
\hline 13. & Celala & - & - & - \\
\hline \multirow[t]{2}{*}{14} & Rusip Between & 10 & 14 & 3,500 \\
\hline & total & 45 & 54 & \\
\hline
\end{tabular}

Planted Area, Harvested Area \& Long Bean Production in Central Aceh District, 2014

Table 5. Planted Area, Harvested Area \& Mustard / Petsai Production

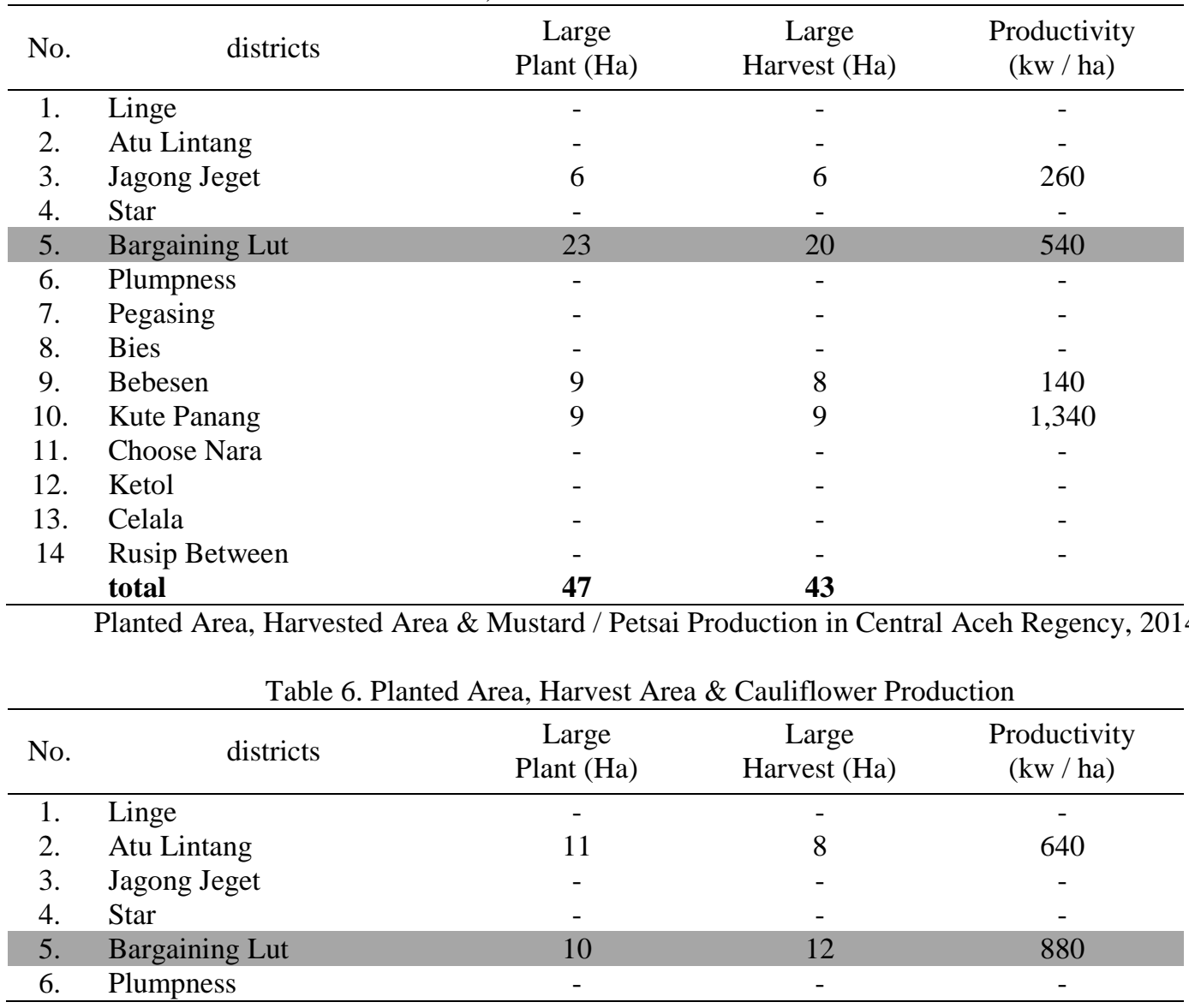




\begin{tabular}{rlccc}
\hline & & & - & - \\
\hline 7. & Pegasing & - & - & - \\
8. & Bies & - & 8 & 160 \\
9. & Bebesen & 8 & 7 & 1,060 \\
10. & Kute Panang & 6 & - & - \\
11. & Choose Nara & - & - & - \\
12. & Ketol & - & - & - \\
13. & Celala & - & - & - \\
14 & Rusip Between & - & $\mathbf{3 5}$ & \\
& total & $\mathbf{3 5}$ & Catiflow Production & \\
\hline
\end{tabular}

Table 7. Total Population

\begin{tabular}{|c|c|c|c|c|c|c|}
\hline \multirow{2}{*}{ No. } & \multirow{2}{*}{ districts } & \multicolumn{5}{|c|}{ Population } \\
\hline & & 2010 & 2011 & 2012 & 2013 & 2014 \\
\hline 1. & Linge & 8,757 & 8,958 & 9,195 & 9,267 & 9,589 \\
\hline 2. & Atu Lintang & 5,804 & 3,935 & 6,092 & 6,140 & 6,354 \\
\hline 3. & Jagong Jeget & 8,871 & 9,074 & 9,314 & 9,387 & 9,715 \\
\hline 4. & Star & 8,504 & 8,699 & 8,929 & 8,998 & 9,312 \\
\hline 5. & Bargaining Lut & 17,960 & 18,372 & 18,858 & 19,005 & 19,667 \\
\hline 6. & Plumpness & 14,041 & 14,362 & 14,742 & 14,857 & 15,374 \\
\hline 7. & Pegasing & 17,640 & 18,044 & 18,521 & 18,666 & 19,317 \\
\hline 8. & Bies & 6,414 & 6,561 & 6,735 & 6,787 & 7,023 \\
\hline 9. & Bebesen & 34,342 & 35,129 & 36,060 & 36,340 & 37,606 \\
\hline 10. & Kute Panang & 6,815 & 6,971 & 7,155 & 7,211 & 7,262 \\
\hline 11. & Choose Nara & 20,542 & 21,012 & 21,658 & 21,736 & 22,493 \\
\hline 12. & Ketol & 11,342 & 11,602 & 11,909 & 12,001 & 12,420 \\
\hline 13. & Celala & 8,367 & 8,558 & 8,784 & 8,853 & 9,161 \\
\hline \multirow[t]{2}{*}{14} & Rusip Between & 6,129 & 6,269 & 6,435 & 6,485 & 6,711 \\
\hline & Central Aceh & 175,527 & 179,546 & 194,297 & 185,733 & 192,204 \\
\hline
\end{tabular}

\section{RESULTS AND ANALYSIS}

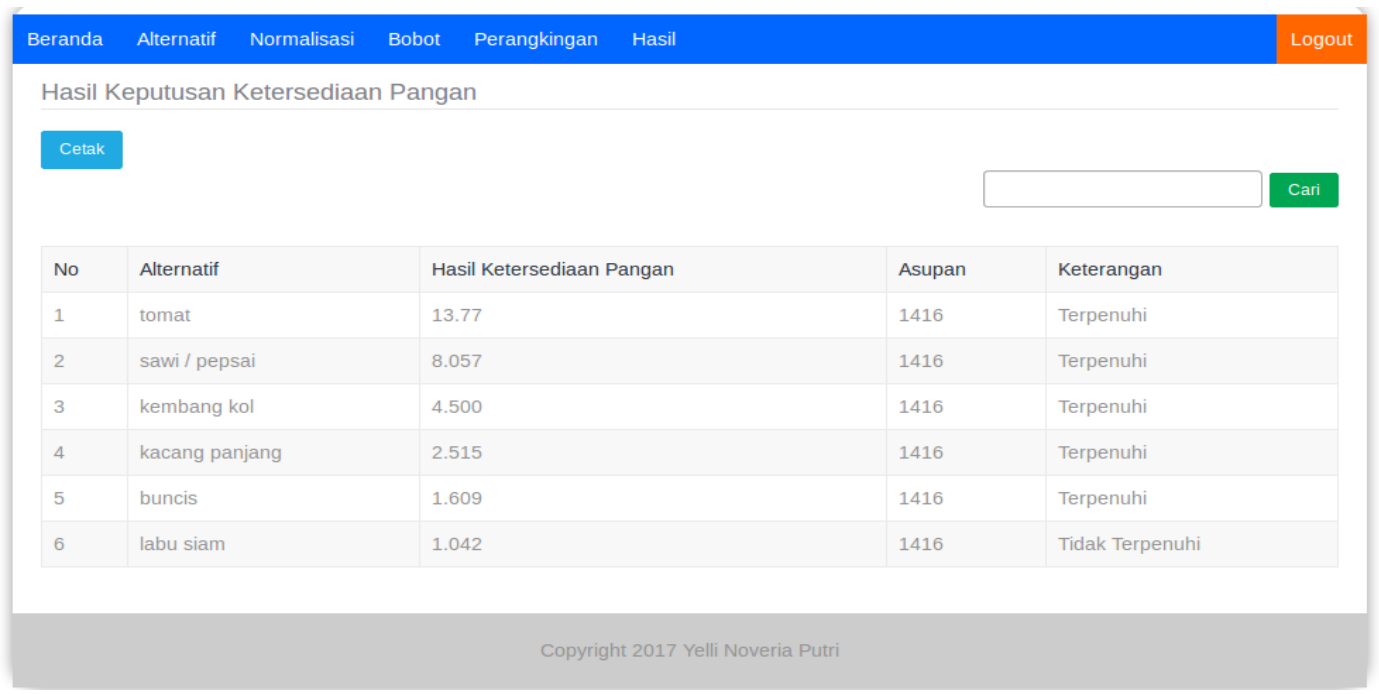

Figure 2. Hasil Keputusan ketersediaan Pangan

This research is a process of collecting and analyzing data which is carried out systematically and logically to achieve certain goals. This research is to test existing theories / sciences for practical purposes 
that are directly useful. The purpose of research on food availability is to obtain decisions about food availability in Lut Tawar District, Central Aceh Regency.

In the case of research This research uses a survey that is to collect as much data as possible about the vegetables found in Lut Tawar District which is a decision support for the quality of the research. Then analyze vegetables in meeting production targets and food availability. The application of the Simple Additive Weighting (SAW) method to the decision support system is to create a decision support system for the availability of food that is assessed from the results of its production.

1) There are 4 criteria used to make the assessment, namely:

a. C1: Productivity

b. C2: Harvested Area

c. C3: Planted Area

d. C4: Total Population

2) Decision making assigns weight to each criterion

Alternative types of vegetables are as follows:
a. Chayote
b. Bean
c. Tomato
d. Long beans
e. Sawi / Petsai
f. Cauliflower

\subsection{Alternative Data Display}

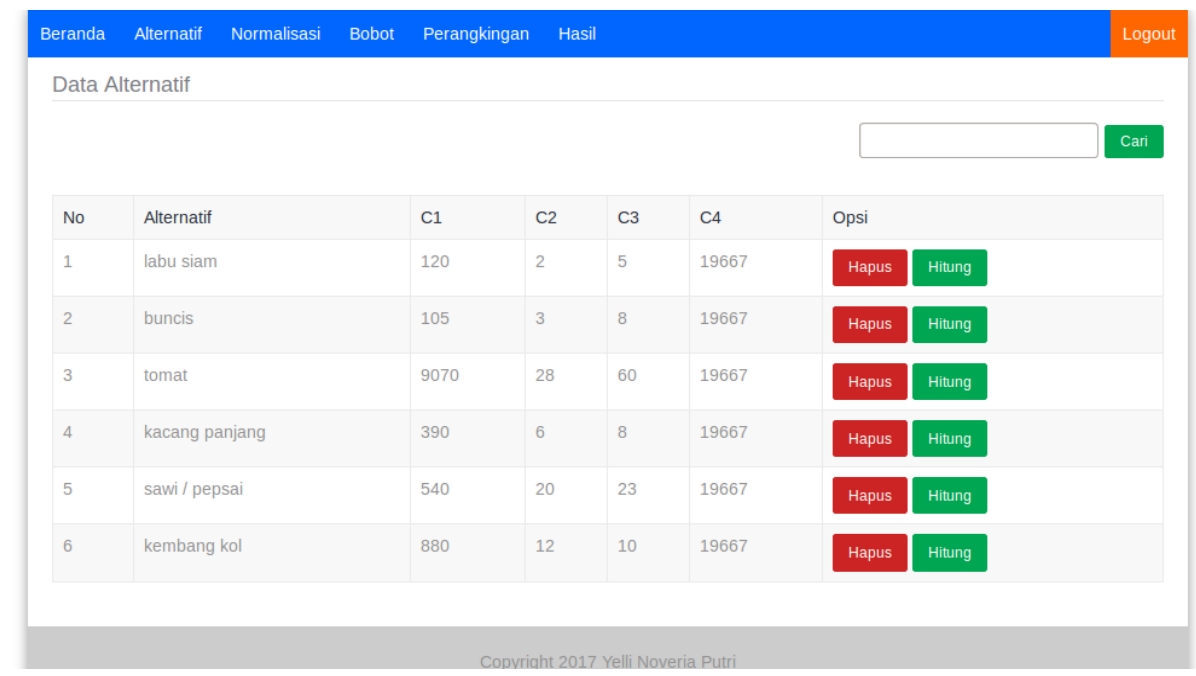

Figure 3. Alternative Data Display

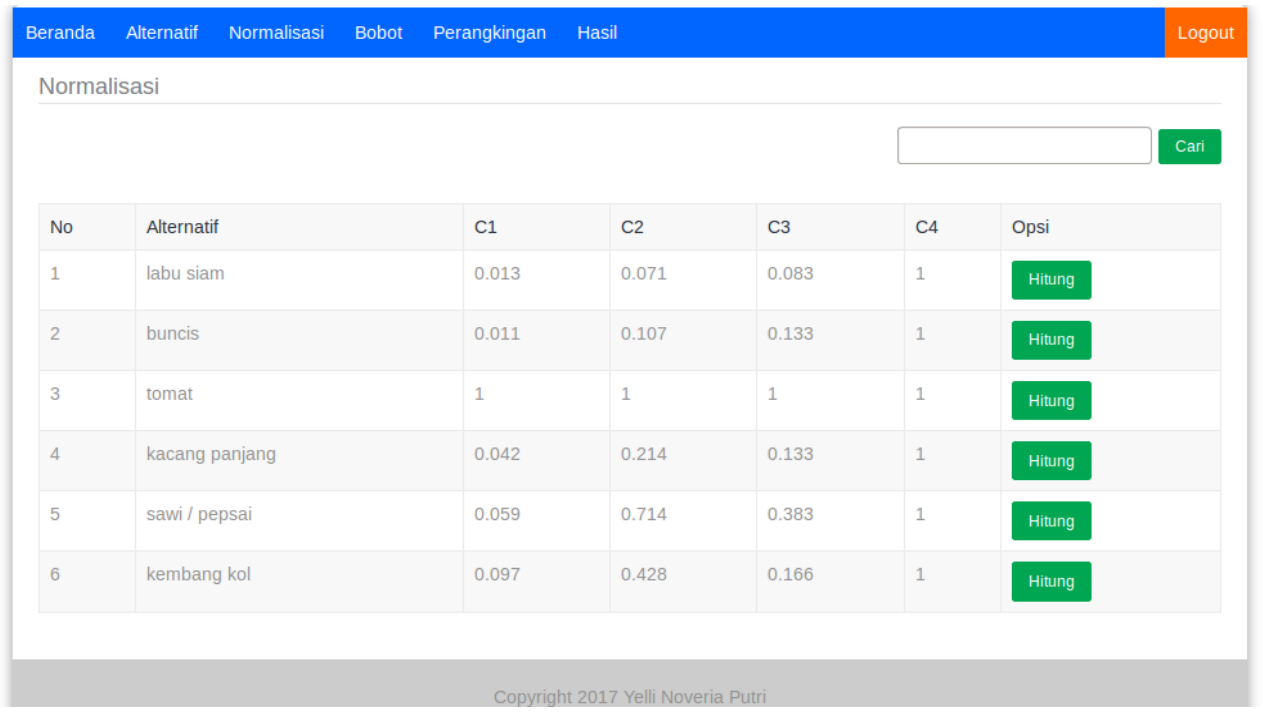

Figure 4. Normalisasi 


\subsection{Data normalization is carried out using the following formula}

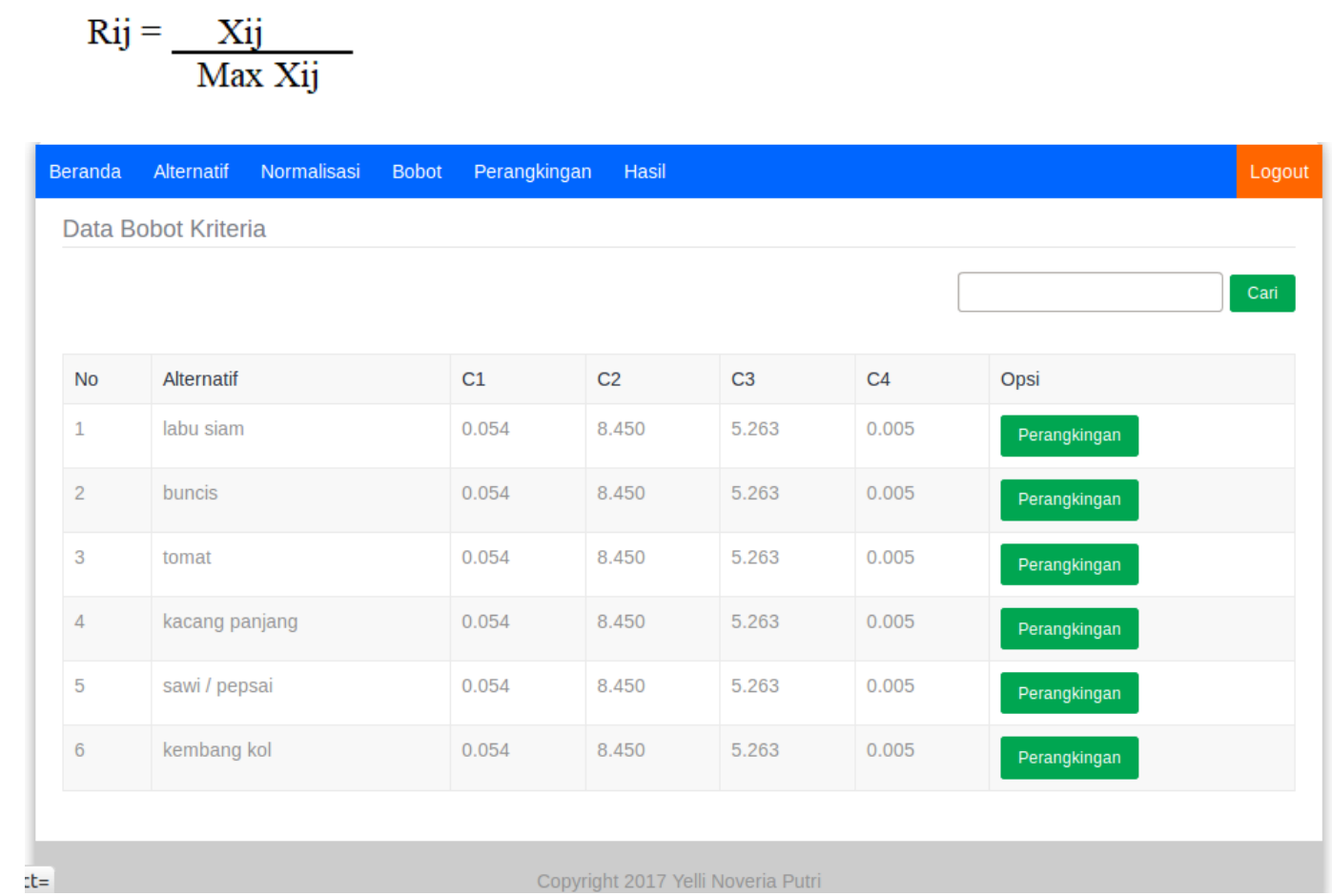

Figure 5. The Ranking Process

The ranking process uses the weight determined by the decision maker using the following formula

$$
\mathrm{V}_{\mathrm{i}}=\sum_{\mathrm{j}=\mathrm{l}}^{\mathrm{n}} \mathrm{w}_{\mathrm{j}} \mathbf{r}_{\mathrm{ij}}
$$

\section{CONCLUSION}

a. Vegetables harvested by the farming community in Lut Tawar Subdistrict can meet their food needs with the exception of the type of chayote.

b. Tomato vegetable is the biggest producer, reaching 13.77 tons per year when compared to other types of vegetables.

c. The Decision Support System using the SAW method is a tool to simplify the process of calculating vegetable yields in Lut Tawar District

\section{REFERENCES}

[1] Departemen Kesehatan R1. 2003. Pedoman Umum Gizi Seimbang (Panduan Untuk Petugas). Jakarta: Departeman Kesehatan Rl. Direktorat Jenderal Bina Kesehatan Masyarakat. Direkorat Gizi Masyarakat

[2] Anonim, 2009.Undang-Undang Negara Republik Indonesia Nomor 36 Tahun 2009, tentang Kesehatan di Indonesia

[3] Olven Manahan "Perancangan Dan Pembuatan Sistem Pendukung Keputusan Penentuan Karyawan Terbaik Dengan Metode Saw Pada Pt Iss Indonesia Cabang Medan”. Jurnal Matik Penusa Volume 19 No. 1 Juni 2016, ISSN 2088-3943 44

[4] Dwi Citra Hartini dkk "Sistem Pendukung Keputusan Pemilihan Hotel Di Kota Palembang Dengan Metode Simple Additive Weighting (SAW)". Jurnal Sistem Informasi (JSI), VOL. 5, NO. 1, April 2013, Halaman 546-565, ISSN Print : 2085-1588 ISSN Online : 2355-4614 
[5] Erni Dianasari, Taufik Baidawi "Sistem Pendukung Keputusan Penilaian Tanaman Anggrek Pada Ud. Sanjiwani Orchid Menggunakan Metode Simple Additive Weighting”. SWABUMI VOL III No. 1, September 2015, ISSN 2355-990X

[6] Fera Tri Wulandari, Setiya Nugroho "Penentuan Produk Kerajinan Unggulan Dengan Menggunakan Madm-Saw”. Pros iding SNATIF Ke -2 Tahun 2015, ISBN: 978-602-1180-21-1.

[7] sqolani, Hasan. 2011. Problem Ketahanan dan Nasib Petani, http://sugiarto agribisnis.wordpress.com/2011/04/24/problem-ketahanan-pangan-dannasib-petani/

[8] jsh Jurnal Sosial Humaniora, Vol 4 No.2, November 2011186

[9] wartasolo, "Macam Sayuran Super Sehat Beserta Manfaat dan Kandungan Gizinya, https://www.google.com/search?q=wartasolo\%2C+\%E2\%80\%9CMacam+Sayuran+Super+Sehat+Bes erta+Manfaat+dan+Kandungan+Gizinya\&oq, diakses 26 Desember 2020.

[10] Aceh Tengah Dalam Angka 2015, "Luas Tanam, Luas panen \& Produksi Tanaman Sayuran Buah musiman di Kabupaten aceh Tengah,2014. ISBN : 0215.3467. hal : 48,171, 173, 175, 178, 181, 182 